\title{
Guidewire Device
}

National Cancer Institute

\section{Source}

National Cancer Institute. Guidewire Device. NCI Thesaurus. Code C50271.

A flexible wire designed to help position medical devices within the body. 